\title{
Giant Resin Bee Megachile sculpturalis (Smith) (Insecta: Hymenoptera: Megachilidae) ${ }^{1}$
}

\author{
Kristen C. Stevens, Cameron J. Jack, and James D. Ellis ${ }^{2}$
}

\section{Introduction}

Originally from eastern Asia, the giant resin bee, Megachile sculpturalis (Smith) (Figure 1), was accidentally introduced into the United States in the 1990s. It is considered an adventive species (i.e., non-native and usually not established), but is present in most states in the eastern US. Although these bees can be found on various plants, they typically prefer plants that have been introduced from their native area. Some have observed that when collecting pollen or nectar, Megachile sculpturalis will damage local flora, making them unusable to future bee visitors (Sumner 2003). Evidence has shown that Megachile sculpturalis pollinates a native and federally threatened plant, Apios pricenana (Campbell 2016).

\section{Distribution}

Megachile sculpturalis is native to China, Japan and a few other locations in eastern Asia. This bee was first intercepted in the US in North Carolina in 1994 at commercial ports; thus, it is believed to have arrived to the US accidentally via international trade. Since coming to the US, it inhabits most states east of the Mississippi River. Based on its native range and preference for humid, subtropical, and temperate climates, it is predicted that this large invasive bee will continue to spread throughout the US (Parys et al. 2015) (Figure 2).

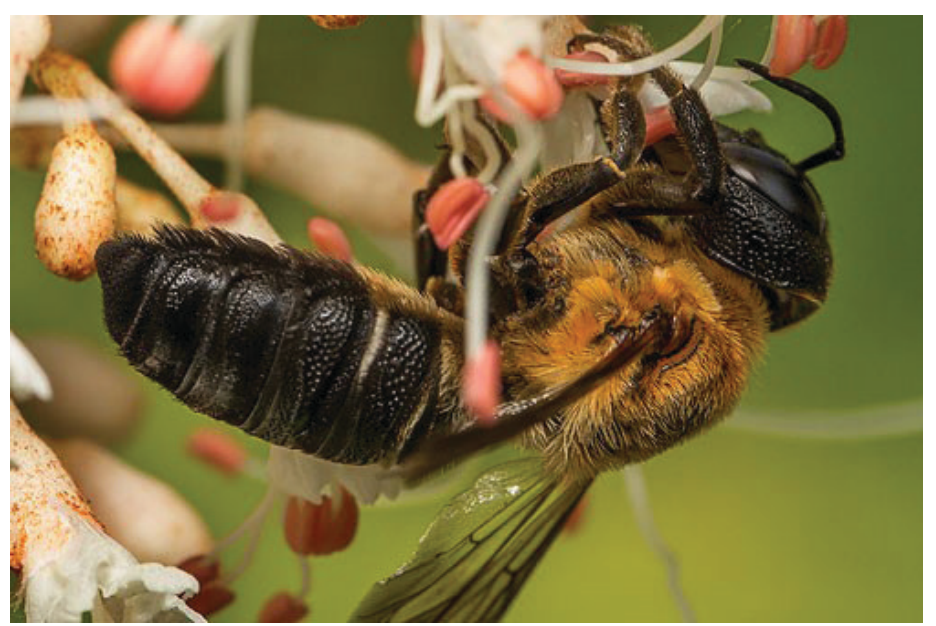

Figure 1. A female giant resin bee, Megachile sculpturalis (Smith), collecting pollen.

Credits: Paula Sharp

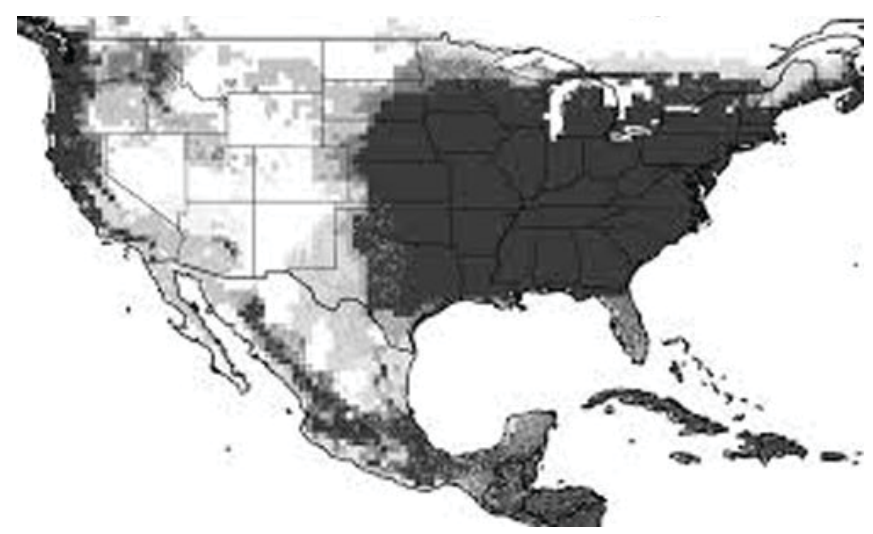

Figure 2. This map shows the predicted distribution of Megachile sculpturalis (Smith).

Credits: Ismael A. Hinojosa-Diaz, University of Kansas

1. This document is EENY-733, one of a series of the Entomology and Nematology Department, UF/IFAS Extension. Original publication date July 2019. Visit the EDIS website at https://edis.ifas.ufl.edu for the currently supported version of this publication. This document is also available on the Featured Creatures website at http://entomology.ifas.ufl.edu/creatures.

2. Kristen C. Stevens; Cameron J. Jack; and James D. Ellis, assistant professor of entomology; Entomology and Nematology Department, UF/IFAS Extension, Gainesville, FL 32611.

The Institute of Food and Agricultural Sciences (IFAS) is an Equal Opportunity Institution authorized to provide research, educational information and other services only to individuals and institutions that function with non-discrimination with respect to race, creed, color, religion, age, disability, sex, sexual orientation, marital status,

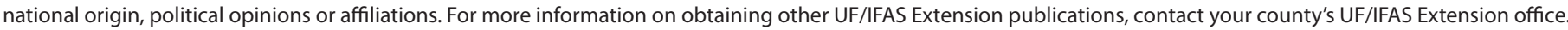
U.S. Department of Agriculture, UF/IFAS Extension Service, University of Florida, IFAS, Florida A \& M University Cooperative Extension Program, and Boards of County Commissioners Cooperating. Nick T. Place, dean for UF/IFAS Extension. 


\section{Description}

Megachile sculpturalis has a large, cylindrical body, which is typically black and yellow-brown in color. The head is dark with yellow-brown setae (insect hairs). These golden hairs can be found on the thorax and the first segment of the abdomen. The female bee, ranging in size from 22 to $27 \mathrm{~mm}$, is typically much larger than the male bee, which ranges in size from 14 to $19 \mathrm{~mm}$. The leafcutting bee, another Megachile, ranges in size from $5 \mathrm{~mm}$ to $24 \mathrm{~mm}$, considerably smaller than the giant resin bee. The female has a more pointed abdomen (Figure 3 ) while the male's abdomen has a blunt edge (Figure 4). The males are distinguished by a line of golden hairs that resemble a moustache directly above the mandibles (Figure 5). Megachile sculpturalis have smoky-colored wings that contain dark marks near the edges. Their wings, while resting, are often held in a V shape on their back (Figure 6).

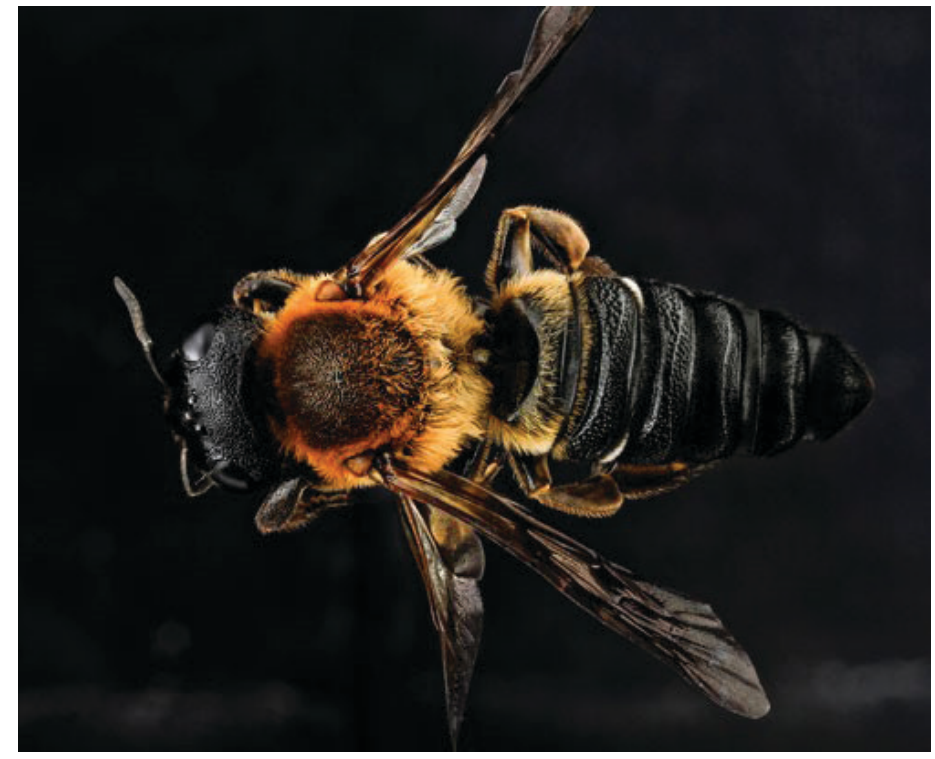

Figure 3. Female Megachile sculpturalis (Smith), note the pointed abdomen.

Credits: Heagan Ahmed and the USGS Bee Inventory and Monitoring Lab

\section{Biology}

Megachile sculpturalis are solitary bees that do not form colonies; however, females of this species have been known to build their nests in the same area as other females (they are gregarious). Like most bees, Megachile sculpturalis is a pollinator of many plant species. They have been observed to forage on 43 species of plants in the US, though they prefer pollen and nectar from plants native to Asia that have been introduced into the United States. These bees are known to be tunnel nesters. They create their nests in narrow grooves in tree cavities, crevices, downed logs and other debris sometimes used by other bee species (Dellinger 2016).

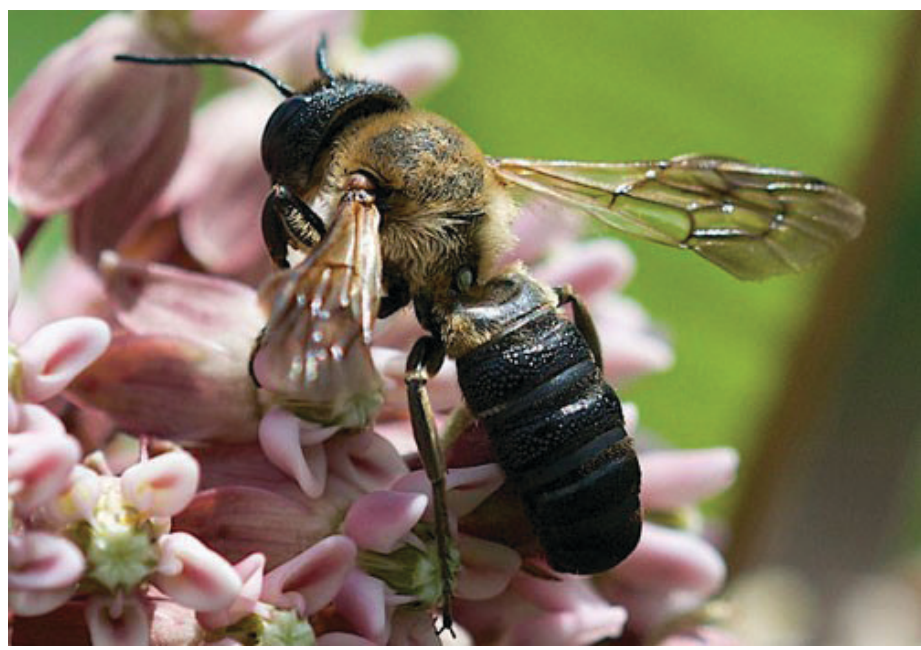

Figure 4. A male Megachile sculpturalis (Smith) pollinating a flower, note the blunted abdomen, which is a defining characteristic of the male of this species.

Credits: Mark Etheridge and the USGS Bee Inventory and Monitoring Lab. Maryland, USA

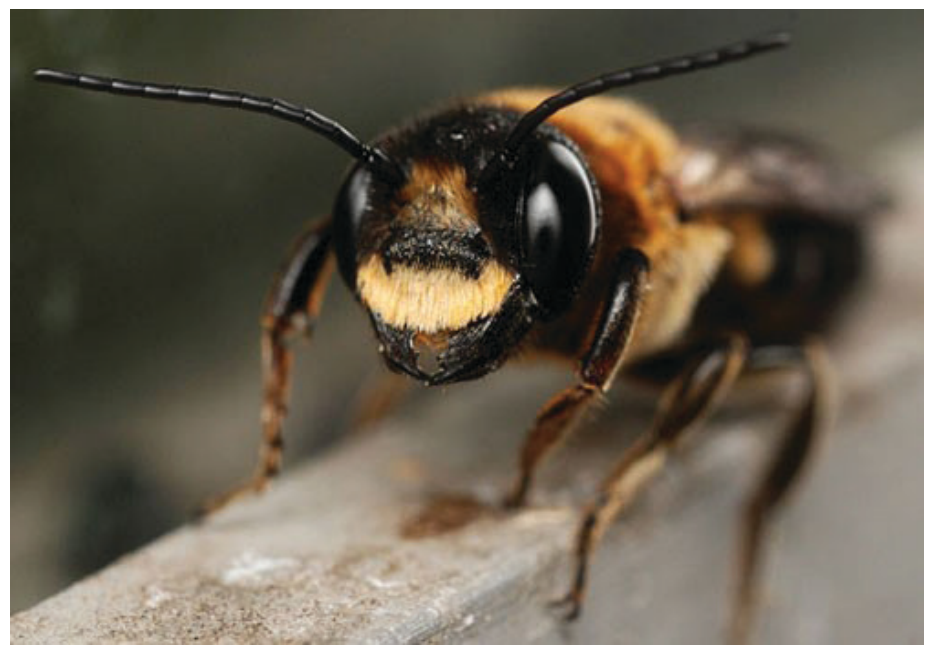

Figure 5. Male Megachile sculpturalis (Smith) with the distinct line of golden hairs above the mandibles.

Credits: Thomas Palmer, Massachusetts, http://bugguide.net/node/ view/836673

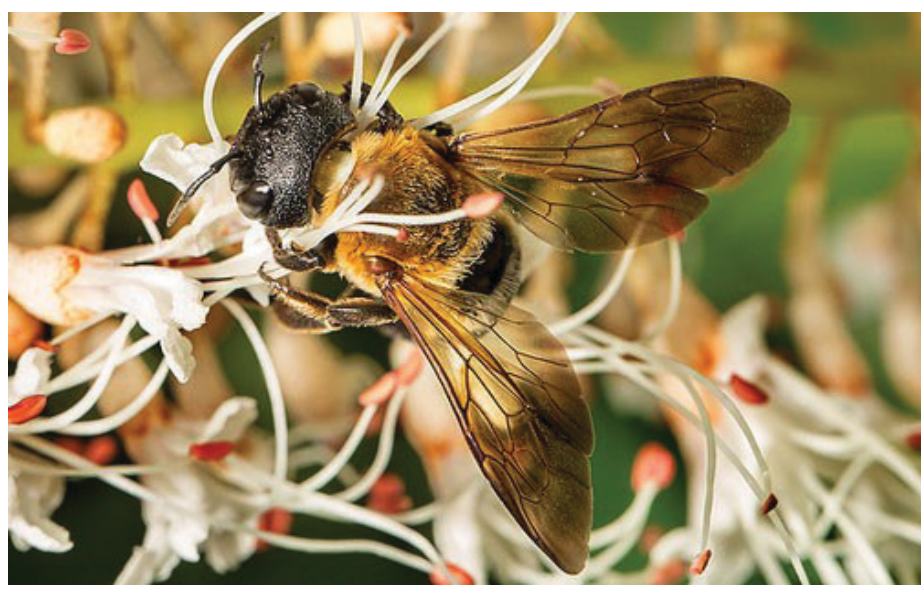

Figure 6. Megachile sculpturalis (Smith) holding its wings in a V-shaped pattern on its back.

Credits: Paula Sharp 
They are known to displace native carpenter bees (Xylocopa spp.) from their cavities in order to nest in them. During the summer months, female Megachile sculpturalis begin constructing brood cells of wood particles and mud, very similar to those of the native carpenter bee (Xylocopa virginica). Females of Megachile sculpturalis will use existing carpenter bee cavities in order to lay their eggs because their mandibles cannot chew through wood to create cavities of their own. They will use other material with pre-existing cavities as nesting habitat such as rotting wood. After several pollen collecting trips, the females form a pollen ball containing pollen and resin in each brood cell and lay a single egg on the pollen ball (Figure 7).

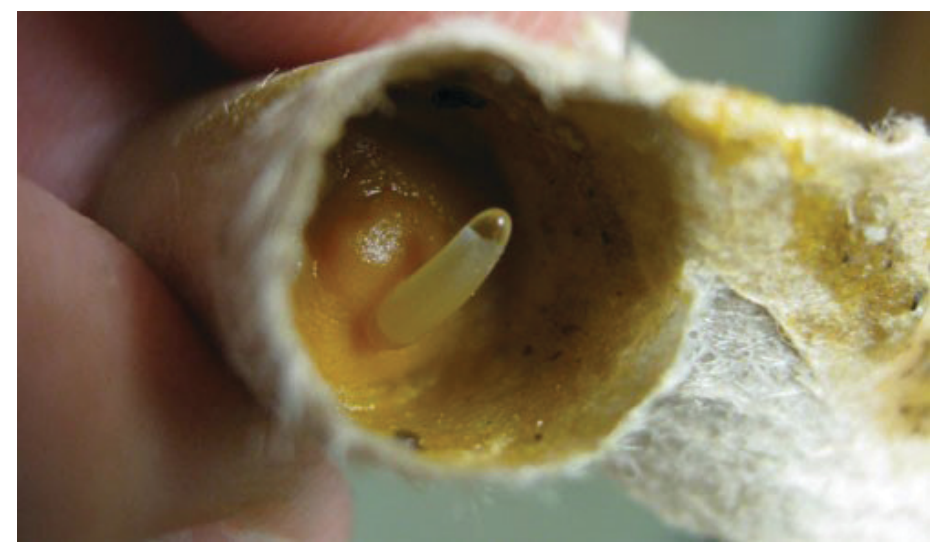

Figure 7. A larva resting on its pollen and resin ball within a brood cell of a Megachile sculpturalis (Smith) nest.

Credits: Alonso Abugattas

The adult female then will seal the cell using a mixture of wood particles, mud, or resin (Figure 8). After the first cell is sealed, the female bee will repeat the process and lay another egg within a separate brood cell. The female can make as many as 10 cells per nest. After emerging, larvae remain in their respective cells and feed on the pollen balls provided to them. They will consume this food throughout the winter. The larvae will pupate during the spring and the adults emerge in early summer.

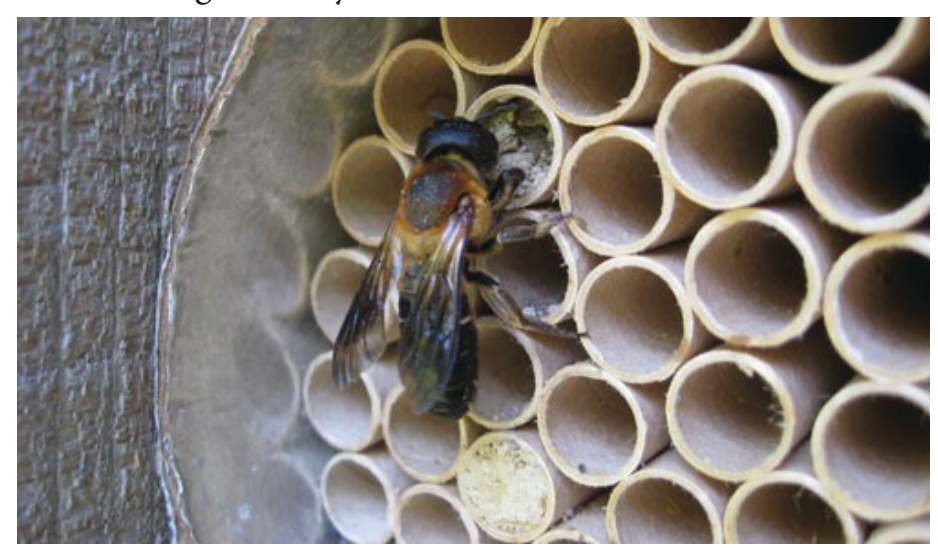

Figure 8. Megachile sculpturalis (Smith) female capping a brood cell with resin and mud.

Credits: Alonso Abugattas

\section{Potential Impact}

Although Megachile sculpturalis' large appearance may make it intimidating, they are largely harmless. The males are unable to sting, and the females, although able to sting, are not aggressive and usually fly away from humans. The overall ecological impact of this bee has been considered benign, since no drastically negative or positive outcomes have been detected by their presence thus far. They are known to pollinate up to 43 different species of plants in the US and do exhibit preferential pollination of plant species from their native habitat. The giant resin bee has been observed to leave puncture marks on the petals of two types of flowers, the everlasting pea and the Japanese pagoda flower. This is a helpful visual marker for researchers studying what plants the giant resin bee visits. This behavior does leave a permanent mark on the flowers, and in other species, a mark like this could have a negative effect on the pollinating ability of the flower.

These bees may negatively affect a native carpenter bee, Xylocopa virginica. Xylocopa virginica are known to chew long narrow cavities in the eaves of homes, which Megachile sculpturalis will use as nest sites. Because of this, Megachile sculpturalis may actually compete with Xylocopa virginica for nesting habitat.

\section{Management}

Because Megachile sculpturalis does not have the ability to chew through wood, it does not cause structural damage and does not need to be controlled aggressively through chemical applications; however, if control becomes necessary, altering their habitat is recommended, specifically, identifying and destroying their nests. This can be done primarily by painting wood in order to deter Xylocopa virginica from making cavities in which Megachile sculpturalis can then inhabit. Xylocopa virginica cavities can be filled with putty, which will make them undesirable to Megachile sculpturalis, causing the female resin bee to relocate in search of alternate nesting sites.

\section{Acknowledgements}

Reviews by Joshua Campbell and Howard Frank, Entomology and Nematology Department, University of Florida; Cory Stanley-Stahr, EAG Laboratory, Alachua, FL. 


\section{Selected References}

Campbell JW, Campbell BE, Kimmel CB, Galvan P. 2016.

"Observations of insect visitor to Price's potato bean (Apios priceana (Fabaceae)) in North Alabama, USA." Plant Ecology and Evolution 149(3): 316-318.

Dellinger DA, Day D. 2014. Giant resin bee. Virginia Polytechnic Institute and State University, Virginia Cooperative Extension, ENTO-96NP. (10 June 2016).

Hinojosa-Diaz IA. 2008. "The giant resin bee making its way west: First record in Kansas (Hymenoptera: Megachilidae)." ZooKeys 1: 67-71 pp. doi 10.3897/zookeys.1.17

Hinojosa-Diaz IA, Yanez-Ordonez O, Chen G, Peterson AT, Engel MS. 2005. "The North American invasion of the giant resin bee (Hymenoptera: Megachilidae)." Journal of Hymenoptera Research 14: 69-77.

Kondo T, Williams ML, Minckley R. "Giant resin bees! Exotic bee species makes its way from east coast to Alabama." Highlights of Agricultural Research 47: 1-4.

Laport RG, Minckley RL. "Occupation of active Xylocopa virginica nest by the recently invasive Megachile sculpturalis in upstate New York." Journal of the Kansas Entomological Society 85: 384-386.

Mangum WA, Bambara S. 1998. Giant resin bee (Megachile sculpturalis Smith). North Carolina State University, Entomology Department, North Carolina Cooperative Extension Service, ENT/ORT-110. (13 June 2016).

Mangum WA, Sumner S. 2003. "A survey of the North American range of Megachile (Callomegachile) sculpturalis an adventive species in North America." Journal of the Kansas Entomological Society 76: 658-662.

Mazurkiewiez M. 2010. “The giant resin bee, Megachile sculpturalis, in Maine: A New State Record." The Maine Entomologist 14: 3.

O’Brien MF, Craves J. 2008. “Megachile sculpturalis Smith - A new bee for Michigan (Hymenoptera: Megachilidae)." Newsletter of the Michigan Entomological Society 53: 1-2.

Paiero SM, Buck M. 2003. "The giant resin bee, Megachile sculpturalis Smith, and other newly introduced and newly recorded native Megachilidae and Andrenidae (Apoidea) from Ontario." Journal of the Entomological Society of Ontario 134: 143-145.
Parys KA, Tripodi AD, Sampson BJ. 2015. “The giant resin bee, Megachile sculpturalis Smith: New distributional records for the Mid-and Gulf- South USA." Biodiversity Data Journal 3: 1--23. doi: 10.3897/BDJ.3.e6733

Quaranta M, Sommaruga A, Balzarini P, Felicioli A. 2015. "A new species for the bee fauna of Italy: Megachile sculpturalis continues its colonization of Europe." Bulletin of Insectology 67: 287-293.

Roulston T, Malfi R. 2012. "Aggressive eviction of the eastern carpenter bee (Xylocopa virginica (Linnaeus)) from its nest by the giant resin bee (Megachile sculpturalis Smith)." Journal of the Kansas Entomological Society 85: 387-388. 